\title{
PERUBAHAN MINSET MENGAJAR DALAM PERSAINGAN PENDIDIKAN DI ERA MEA
}

\author{
Muhamad Alwi \\ Universitas Islam Attahiriyah Jakarta \\ Email:alawimuhamad@gmail.com
}

\begin{abstract}
Abstrak
Tugas dan tanggung jawab pendidik saat ini dan masa yang akan datang akan makin kompeks. Mengajar bukan hanya sekedar menyampaikan materi, memenuhi jam mengajar, menggugurkan kewajiban dll. Pandangan seperti ini kurang bahkan tidak tepat. Hal ini diperlukan perubahan cara pandang atau cara berfikir (mindset) dari para pelaku perubahan itu sendiri yakni pendidik. Ketika mengajar diartikan sebagai proses membimbing pengalaman belajar peserta didik maka, pandangan sebagaimana tersebut tidak pernah terjadi. Hal ini pula yang mendasari perlu adanya perubahan mindset mengajar seorang pendidik dalam menghadapi persaingan pendidikan di era MEA maupun persaingan dalam kancah yang lain. Sehingga mutu pendidikan dan kualitas pendidik di Indonesia dapat bersaing dengan Negaranegara ASEAN yang lain.
\end{abstract}

Kata Kunci : Perubahan, Mindset, Mengajar, MEA 


\section{PENDAHULUAN}

Pandangan mengajar hanya sebatas transfer of knowledge (menyampaikan ilmu pengetahuan) itu dianggap sudah tidak relevan lagi dengan kondisi saat ini. Alasan inilah yang kemudian menuntut perlu terjadinya perubahan mindset dalam mengajar. Peran dan tanggung jawab seorang pendidik saat ini dan masa mendatang akan makin kompleks. Hal ini dibutuhkan kompetensi seorang pendidik yang berkualitas dalam berkompetisi di MEA. Berhasil dan tidaknya suatu proses pembelajaran sangat ditentukan oleh kualitas seorang pendidik dalam penyelenggaraan kegiatan tersebut, meskipun pendidik itu bukanlah satu-satunya sumber maupun subjek pembelajaran. Namun tuntutan bahwa pendidik harus memahami materi pembelajaran sebelum mengajar merupakan suatu keniscayaan. Hal tersebut senada dengan ungkapan Anies Baswedan, "Pendidik adalah ujung tombak proses pendidikan". Tanpa guru, tidak mungkin bangsa Indonesia bisa membuat konversi tingkat melek huruf dari $5 \%$ menjadi $92 \%$. Tanpa guru, tidak mungkin program pendidikan sekolah universitas dapat berhasil. Tanpa guru, tidak mungkin muncul generasi berkualitas. ${ }^{1}$ Hal yang sama juga dikatakan bahwa pendidikan yang berkualitas hanya muncul apabila terdapat guru yang berkualitas. ${ }^{2}$ Semua fakta dan pendapat tersebut semakin mempertegas bahwa memperbaiki mutu pendidikan maka memprioritaskan perbaikan kualitas guru menjadi suatu keniscayaan.

Jika mencermati perkembangan mutu pendidikan di Indonesia pada suatu dekade terkhir, mutu sekolah pada kenyataannya masih jauh dari harapan. Mutunya masih tertinggal disbanding dengan Negara-negara tetangga di ASEAN, seperti Malaysia dan Singapura. Dari beberapa lembaga internasional sebagai berikut: pertama, hasil survey TIMS yang dilakukan oleh Global Institute pada tahun 2007 menunjukkan hanya $5 \%$ peserta didik Indonesia yang mampu mengerjakan soal penalaran tinggi; padahal Korea dapat mencapai $71 \%$. Sebaliknya, $78 \%$ peserta didik Indonesia mampu mengerjakan soal hafalan berkategori rendah sementara peserta didik Korea hanya $10 \%$. Kedua, hasil studi PISA tahun 2009 menempatkan Indonesia pada peringkat

1 Munif Chotib. Gurunya Manusia: Menjadikan Semua Anak Istimewa dan Semua Anak Juara (Bandung: Kaifa, 2014) h. xiv

2 Zahroni. Dinamika Peningkatan Mutu (Yogyakarta: Galvin Kalam Utama, 2011) h. 99 
bawah 10 besar dari 65 negara peserta PISA. Dalam penelitian itu diungkapkan bahwa semua peserta didik Indonesia ternyata hanya menguasai pelajaran sampai level 3 saja, sementara peserta didik dari banyak Negara yang lain dapat menguasai pelajaran sampai level 5 bahkan 6. Dari kedua survey itu lalu disimpulkan bahwa prestasi peserta didik Indonesia tertinggal dan terbelakang. ${ }^{3}$ Hal tersebut juga diperkuat dua indikasi di lapangan sebagai berikut: pertama, masih rendahnya kualitas hasil belajar yang ditandai oleh standar kelulusan yang ditetapkan, yaitu 4,25 dari skala 10 dan 4,50 pada tahun 2008. Seorang siswa dinyatakan lulus meskipun hanya mampu menyerap mata pelajaran sebesar $4,25 \%$, dengan standar kelulusan yang rendah pun masih banyak siswa yang tidak lulus pada Ujian Nasional 2007. Nilai Ujian Nasional ini ternyata masih di bawah Negara tetangga seperti Malaysia dan Singapura. Kondisi ini menunjukkan peserta didik kurang dapat bersaing dengan Negara-negara tetangga. Walaupun angka kelulusan ujian nasional setiap tahun mengalami kenaikan, tetapi masih di bawah Negara-negara Asia yang lain yang telah mematok angka di atas. Indikasi kedua, yakni angka ketidaklulusan ujian nasional (UN) tahun 2004/2005 lebih tinggi bila dibandingkan dengan tahun 2003/2004. Namun bila dilihat dari nilai rata-rata yang dicapai terdapat peningkatan yang cukup berarti yakni dari 5,55 tahun 2003/2004 menjadi 6,76 pada tahun $2014 / 2015 .{ }^{4}$ Kondisi ini tentunya sangat memprihatinkan dan perlu mendapatkan perhatian yang serius dari pemerintah maupun lembaga pendidikan serta yang tidak kalah pentingnya adalah perlu adanya perubahan mindset maupun paradigma mengajar.

Pandangan mengajar yang hanya sebatas menyampaikan ilmu pengetahuan itu, dianggap sudah tidak sesuai lagi dengan keadaan. Mengapa demikian? Minimal ada tiga alasan penting. Alasan inilah yang kemudian menuntut perlu terjadinya perubahan paradigma mengajar, perubahan dari mengajar hanya sebatas menyampaikan materi pelajaran kepada mengajar sebagai proses mengatur lingkungan.

Pertama, siswa bukan dewasa dalam bentuk mini, tetapi mereka adalah organisme yang sedang berkembang. Agar mereka

3 E. Mulyasa. Pengembangan Implementasi Kurikulum 2013 (Bandung: Remaja Rosdakarya, 2013) h. 60

4 Mohammad Ali. Pendidikan dan Pembangunn Nasional (Bsndung: Imperial Bhakti Utama) h. 252- 259 
dapat melaksanakan tugas-tugas perkembangannya, dibutuhkan orang dewasa yang dapat mengarahkan dan membimbing mereka agar tumbuh dan berkembang secara optimal. Oleh karena itulah, kemajuan pengetahuan dan teknologi, khususnya tsknologi informasi yang memungkinkan setiap siswa dapat dengan mudah mendapatkan berbagai informasi, tugas, dan tanggung jawab guru bukan semakin sempit namun justru semakin kompleks. Guru bukan hanya dituntut untuk lebih aktif mencari informasi yang dibutuhkan, akan tetapi ia juga harus mampu menyeleksi berbagai informasi, sehingga dapat menunjukkan pada siswa informasi yang dianggap perlu dan penting untuk kehidupan mereka. Guru harus menjaga siswa agar tidak terpengaruh oleh berbagai informasi yang dapat menyesatkan dan mengganggu pertumbuhan dan perkembangan mereka. Guru tidak lagi memposisikan diri sebagai sumber belajar yang bertugas menyampaikan informasi, tetapi harus berperan sebagai pengelola sumber belajar untuk dimanfaatkan siswa itu sendiri.

Kedua, ledakan ilmu pengetahuan mengakibatkan kecenderungan setiap orang tidak mungkin dapat menguasai setiap cabang kelimuan. Begitu hebatnya perkembangan ilmu biologi, ilmu ekonomi, hukum dan lain sebagainya. Apa yang dulu tidak pernah terbayangkan sekarang menjadi kenyataan. Dalam bidang teknologi, begitu hebatnya orang menciptakan benda-benda mekanik yang bukan hanya diam, tapi bergerak, bahkan bisa terbang menembus angkasa luar. Demikian juga kehebatan para ahli yang bergerak dalam bidang kesehatan yang mampu mencangkok organ tubuh manusia sehingga menambah harapan hidup manusia. Semua dibalik kehebatan-kehebatan itu bersumber dari apa yang kita sebut sebagai pengetahuan. Abad pengetahuan itulah yang seharusnya menjadi dasar perubahan. Bahwa belajar, tak hanya sekadar menghafal informasi, mengahafal rumus-rumus, tetai bagaimana menggunakan informasi dan pengetahuan itu untuk mengasah kemampuan berfikir.

Ketiga, penemuan-penemuan baru khususnya dalam bidang psikologi, mengakibatkan pemahaman baru terhadap konsep perubahan tingkah laku manusia. Dewasa ini, anggapan manusia sebagai organism yang pasif yang perilakunya dapat ditentukan oleh lingkungan seperti halnya aliran behavioristik, telah banyak ditinggalkan orang. Orang sekarang lebih percaya, bahwa manusia adalah organism yang memilki potensi seperti yang dikembangkan oleh aliran kognitif holistik. Potensi itulah 
yang akan menentukan perilaku manusia. Oleh karena itu, proses pendidikan bukan lagi memberikan stimulus, akan tetapi usaha mengembangkan potensi yang dimilki. Disini siswa tidak lagi anggap sebagai objek, tetapi sebagai subjek belajar yang harus mencari dan mengkonstruksi pengetahunnya sendiri. Pengetahuan itu tidak diberikan akan tetapi dibangun oleh siswa. ${ }^{5}$ Ketiga hal di atas, menuntut perubahan makna dalam mengajar. Mengajar jangan diartikan sebagai proses menyampaikan materi pembelajaran, atau memberikan stimulus sebanyak-banyaknya kepada siswa, akan tetapi lebih dipandang sebagai proses mengatur lingkungan agar siswa belajar sesuai dengan kemampuan dan potensi yang dimilikinya.

\section{PERUBAHAN MINDSET MENGAJAR}

Perubahan belum akan berhasil sebelum kita berhasil mengubah cara pandang dan berfikir para pelaku perubahan. Perubahan bukanlah semata-mata mengubah alat, teknologi, sistem, organisasi dan sebagainya. Melainkan mengubah attitude melalui cara berfikir. ${ }^{6}$ Dengan kata lain, untuk mengubah paradigma mengajar seorang guru dari mengajar hanya menyampaikan menjadi menanamkan keterampilan. Mengajar memenuhi jam mengajar menjadi mengajar untuk memenuhi kebutuhan peserta didik, dan mengajar untuk menggugurkan kewajiban menjadi mengajar membimbing dan menanamkan kepada peserta didik akan aspek kognitif, afektif dan psikomotorik. Agar proses pembelajaran mata pelajaran tertentu dapat terlaksana dengan baik, salah satu yang perlu dibenahi adalah perbaikan kualitas tenaga pengajarnya. ${ }^{7}$

Istilah mindset terdiri dari dua kata, yaitu mind dan set. Mindset sebagai satu istilah bermakna kepercayaan (belief) atau sekumpulan kepercayaan (set of beliefs) atau cara berfikir yang memengaruhi perilaku (behavior) dan sikap (attitude) seseorang, yang akhirnya akan menentukan level keberhasilan hidupnya. Dengan demikian, untuk mengubah mindset seseorang maka belief atau kumpulan belief orang tersebut harus diubah terlebih dahulu. ${ }^{8}$ Sementara itu, untuk memahami mengapa masih banyak

\footnotetext{
5 Wina Sanjaya. Strategi Pembelajaran Berorientasi Strandar Proses Penilaian (Jakarta: Prenada media, 2013), h. 100-102.

6 Renald Kasali dalam kata pengantar buku The Scecret of Mindset karya Andi W. Gunawan (Jakarta: Gramedia Pustaka Utama, 2008) cet. III, h. xii

7 Amiruddin. Perencanaan Pembelajaran (Yogyakarta: 2016) h. 34

8 Adi W. Gunawan, op. cit., h. 13-15
} 
guru yang belum bisa melakukan tranformasi dalam mengajar, dapat dijelaskan sebagai berikut: manusia menurut filosofi Transformational Thinking terdiri dari tiga sistem yaitu sistem perilaku (behavior system), sistem berfikir (thinking system), dan sitem kepercayaan (belief system). Sistem perilaku adalah cara manusia berinteraksi dengan dunia luar, juga interaksi manusia dengan realitas sebagaimana manusia mengerti realitas tersebut. Perilaku seseorang mempengaruhi pengalamannya, demikian pula sebaliknya. Selanjutnya pengalaman akan mempengaruhi sistem berfikir. Sistem berfikir berlaku sebagai filter dua arah yang menerjemahkan berbagai kejadian atau pengalaman yang dialami seseorang menjadi suatu kepercayaan (belief). Selanjutnya, kepercayaan (belief) tersebut akan mempengaruhi tindakan seseorang, sehingga menciptakan realitas bagi dirinya. Sedangkan sistem kepercayaan adalah inti dari segala sesuatu yang diyakini seseorang sebagai realitas, kebenaran, nilai hidup, dan segala sesuatu yang diketahui seseorang mengenai dunia ini.

Namun fakta di lapangan selama ini meskipun pemerintah maupun instansi lain telah mengadakan pelatihan/workshop dalam rangka peningkatan kualitas mengajar, tetapi hasilnya masih belum banyak mengalami perubahan masih banyak kita jumpai mereka mengajar yang monoton, menyampaikan tugas, memberikan PR dll. Mengapa demikian? Karena adanya mekanisme homeostasis dalam diri manusia. Jadi semua hambatan dalam proses perubahan, baik hambatan yang bersifat sadar maupun tidak sadar, merupakan hasil kerja dari kekuatan terbesar dalam perilaku manusia yaitu homeostasis. Homeostasis adalah kecenderungan untuk selalu tetap di posisi yang sama. Homeostasis sangat baik dan bertujuan melindungi diri manusia dari perubahan yang mendadak dan tidak diinginkan. Homeostasis menjaga manusia agar manusia tidak mudah berubah akibat pengaruh orang lain maupun lingkungan. Namun, homeostasis juga menjadi penghambat perubahan saat seseorang ingin mengubah dirinya ke arah yang lebih baik. Dengan kata lain, setiap perubahan yang akan dilakukan seseorang pasti akan mendapatkan perlawanan (resistensi) dari homeostasis. Resistensi adalah mekanisme pertahanan pikiran bawah sadar yang bertujuan melindungi diri seseorang dari situasi yang (dipandang) tidak menyenangkan. Oleh karenanya, perubahan bukanlah hal 
yang menyakitkan, sebab resistensi terhadap proses perubahanlah yang membuat perubahan menjadi sesuatu yang menyakitkan. ${ }^{9}$

Sementara itu, untuk menggantikan sebuah belief system yang telah terbentuk dipikiran bawah sadar seseorang seringkali tidak mudah. Belief system terbentuk dari penerimaan informasi secara terus-menerus dalam rentang waktu yang cukup lama dan telah menjadi kebiasaan. Oleh karenanya, saat menerima informasi yang berlawanan atau dianggap oleh pikiran bawah sadar sebagi sesuatu hal yang baru dan bertentangan maka informasi tersebut lebih banyak menerima penolakan. Sebuah belief system baru hanya dapat dibentuk melalui pemberian informasi yang masuk akal, bermanfaat, dan berdaya guna, bahkan kadang-kadang masih diperlukan perulangan kegiatan pemberian informasi untuk memperkuatnya. ${ }^{10}$ Secara rinci dijelaskan bahwa ada lima hal yang dapat membentuk belief system seseorang, yaitu: repetisi (pengulangan), identifikasi kelompok atau keluarga, ide yang disampaikan oleh figure yang dipandang memiliki otoritas, informasi yang disampaikan melalui emosi yang intens, dan informasi diterima dalam kondisi relaks (keadaan alpha). ${ }^{11}$ Setelah belief telah terbentuk atau ditetapkan, ada dua proses alamiah yang bekerja mempertahankan kelangsungan belief tersebut, yaitu: bias konfirmasi (confirmatory bias) atau validasi subjektif (subjective validation) atau efek validasi personal (personal validation effect); dan kedua, kompas mental. Bias konfirmasi adalah kecenderungan seseorang untuk hanya menerima atau memperhatikan informasi yang sejalan denagn belief yang dimilikinya. Jika informasi tersebut tidak sejalan atau bahkan bertentangan dengan beliefnya, maka orang tersebut akan mengabaikan informasi tersebut. Padahal belum tentu informasi tersebut salah. Sedangkan kompas mental adalah jalur psikologis yang akan digunakan oleh seseorang jika dirinya menemui situasi sulit, tidak pasti, ataun membingungkan. Belief adalah kompas mental yang akan membentu sesorang membuat keputusan terhadap situasi yang tidak menentu. Disini yang membedakan belief positif dan belief negatif adalah dengan memperhatikan efek yang ditimbulkannya terhadap diri seseorang. Belief positif akan mendukung

\footnotetext{
9 Adi W. Gunawan, op. cit., h. 20

${ }^{10}$ Willy Wong, Membongkar Rahasia Hipnosis (Jakarta: Visimedia, 2010) cet. III, h. 25-29

${ }^{11}$ Adi W. Gunawan, op. cit., h. 37-41
} 
pencapaian keberhasilan seseorang dengan melakukan upaya maksimal sedangkan belief negatif adalah yang menghambat pencapaian keberhasilan seseorang dengan tidak berupaya secara tidak maksimal. $^{12}$

\section{MINDSET "DRIVER" SEORANG GURU DI ERA MEA}

Salah satu mindset positif dan penting untuk menghadapi era kompetisi dan siap bersaing dengan Negara-negara ASEAN lainnya; seperti Malaysia, Singapura, Brunai Darussalam dan lain sebagainya adalah harus memiliki mindset seorang driver. Makna "driver" adalah sebuah sikap hidup atau cara pandang yang membedakan dirinya dengan "passenger". ${ }^{13}$ Sebagai driver, guru bisa hidup di mana pun mereka berada dan selalu menumbuhkan harapan. Sebagai seorang driver, guru mengajak orang-orang di sekitarnya untuk berkembang dan keluar dari tradisi lama menuju tanah harapan baru. Mereka melakukan pembaharuan dan menantang keterkungkungan dengan penuh keberanian. Mereka berinisiatif memulai perubahan tanpa ada yang memerintahkan namun rendah hati dan kaya empati. Adapun perbedaan mindset antara driver dan passenger diungkapkan Kasali dalam tabel berikut;

Tabel. Perbedaan Mindser Passenger dan Driver

\begin{tabular}{ll}
\hline \multicolumn{1}{c}{ Passenger } & \multicolumn{1}{c}{ Driver } \\
Hanya menumpang & $\begin{array}{l}\text { Mengemudikan kendaraan } \\
\text { menuju titik tertentu }\end{array}$ \\
$\begin{array}{l}\text { Tidak harus tahu arah jalan } \\
\text { Boleh mengantuk, boleh tidur }\end{array}$ & $\begin{array}{l}\text { Mutlak harus tahu jalan } \\
\text { Dilarang mengantuk apalagi } \\
\text { tidur }\end{array}$ \\
Tidak perlu marawat kendaraan & $\begin{array}{l}\text { Harus mampu merawat } \\
\text { kendaraan } \\
\text { Sebuah pilihan yang bebas dari }\end{array}$ \\
$\begin{array}{l}\text { Sebuah pilihan mengekspos } \\
\text { diri pada bahaya }\end{array}$ \\
\hline
\end{tabular}

Sumber : Kasali, 2014:9

Driver's mentality pada dasarnya adalah sebuah kesadaran yang dibentuk oleh pengalaman dan pendidikan. Jadi seorang driver tidak cukup hanya bermodalkan tekad dan semangat, ia

\footnotetext{
${ }^{12}$ Adi W. Gunawan, op. cit., h. 41-45

${ }^{13}$ Renald Kasali. Self Driving: Menjadi Driver atau Passenger (Jakarta Selatan: Mizan 2014) h. 6-8
} 
juga membutuhkan referensi dari pengetahuan akademis. ${ }^{14}$ Prinsip seorang driver adalah inisiatif, melayani, navigasi, dan tanggung jawab. ${ }^{15}$ Implementasinya guru dalam menghadapi di era MEA yaitu: pertama, guru harus selalu inisiatif. Maksudnya adalah para guru mampu bekerja tanpa harus disuruh, sadar akan tugas dan tanggung jawabnya. Bahwa mengajar bukan hanya masuk kelas saja namun, setelah masuk ke dalam kelas sadar apa yang harus dilakukan. Suatu contoh di dalam kelas guru mendapati siswa yang ramai, lari-larian atau bahkan tidur di dalam kelas, guru punya inisiatif apa yang harus dilakukan supaya siswa siap belajar dengan kondisi pembelajaran yang PAIKEM (pembelajaran, aktif, inovatif, kreatif, edukatif dan menyenangkan).

Kedua, guru harus mampu melayani. Maksudnya memberikan pelayanan yang prima kepada semua siswa tanpa memandang latar belakang ekonomi maupun pendidikan orangtuanya. Semua siswa di mata guru sama maka, sudah sepantaskan mereka mendapatkan perlakukan yang sama. Guru bukan hanya menyampaikan materi, tapi guru mau menerima keluhan, curhatan bahkan pengaduan yang disampaikan siswa. Sehingga mereka merasa diorangkan, dihargai dan diperhatikan.

Ketiga, guru harus memilki tujuan dan target yang jelas (navigasi). Maksudnya mengajar bukan hanya sekedar pemenuhan jam dalam seminggu harus tercapai 24 jam tatap muka, namun guru juga harus mampu merencanakan pembelajaran dengan baik ia sebelum mengajar, sehingga tujuan dan target yang diinginkan dapat berhasil dengan baik. Keberhasilan proses kegiatan belajar mengajar ditentukan oleh perencanaan yang matang. Perencanaan yang dilakukan dengan baik, maka setengah keberhasilan sudah dapat tercapai, setengahnya lagi terletak pada pelaksanaan. Perencanaan yakni suatu cara yang memuaskan untuk membuat kegiatan dapat berjalan dengan baik, disertai dengan berbagai langkah antisipatif guna memperkecil kesenjangan yang terjadi sehingga kegiatan tersebut mencapai tujuan yang telah ditetapkan. ${ }^{16}$

Keempat, guru harus mau dan mampu bekerja secara tanggung jawab. Guru yang baik adalah guru yang sadar akan tugas dan tanggung jawabnya sebagai pendidik. Hasil pendidikan

\footnotetext{
${ }^{14}$ Renald Kasali. op. cit., h. 8

${ }^{15}$ Ibid.

${ }^{16}$ Amiruddin. op. cit., h. 3
} 
merupakan bagian dari tanggung jawab seorang guru, namun yang tidak kalah pentingnya adalah bagaimana proses pembelajaran itu dilaksanakan. Jadi tanggung jawab guru tidak hanya apa (what) yang dihasilkan namun juga bagaimana (how) proses itu dilaksanakan.

Adapun mentalitas guru yang telah menjadi "driver" yaitu ditandai dengan: pertama, sangat tidak puas dengan keadaan sekarang (status quo); kedua, menyukai tantangan-tantangan baru, mengeksplorasi peluang-peluang baru; ketiga, memecahkan masalah bersama, menginspirasi orang lain; keempat, bekerja denga hati, mencintai sesame, menjaga hubungan baik, memiliki kepedulian; kelima, memimpin dengan pertanyaan, memperbaiki cara berfikir penumpang-penumpangnya (para peserta didik maupun rekan seprofesi); keenam, memberikan arah jalan yang jelas, merangkul orang-orang yang berbeda paham dengannya; ketujuh, berani melakukan kesalahan-kesalahan kecil dan mengambil resiko; kedelapan, sangat mencintai perubahan, namun rendah hati, dan penuh empati; kesembilan, dikendalikan oleh creative thinking; kesepuluh, selalu belajar hal-hal baru; kesebelas, membebaskan para sandera dari penumpang yang membajak organisasi. ${ }^{17}$

Mentalitas "driver" dalam perubahan mindset mengajar dalam persaingan pendidikan di era MEA adalah good driver bukan bad driver. Bad driver adalah kumoulan dari orang-orang yang sakit hati, agresif, mudah tersulut kebencian, tidak menentukan arah tindakannya, lebih mencari pembenaran ketimbang kebenaran, dan senag membuat alasan-alasan untuk menutupi kekalahan atau kesalahan-kesalahannya. Mereka adalah orang-orang yang terlatih, tetapi mereka tidak tahu menempatkan diri, kapan harus berbicara dan kapan harus mendengarkan, kapan harus bergerak maju dan kapan harus mundur. Mereka bergerak cepat, berinisiatif tinggi, tetapi selalu menimbulkan masalah. Mereka sebenarnya orang-orang yang secara kualifikasi akademis dan skill-nya sangat mumpuni tetapi memiliki karakter yang buruk. Dengan demikian, orang-orang seperti itu harus dijauhi (atau diterapi). ${ }^{18}$ Sedangkan good driver adalah seorang inisiator, tokoh perubahan, dan mampu menjadi role model bagi banyak orang. Merak tidak sekedar memiliki aneka kompetensi yang memampukan untuk mengambil keputusan-keputusan penting

\footnotetext{
${ }^{17}$ Renald Kasali. op. cit., h. 42-42

${ }^{18}$ Renald Kasali. op. cit., h. 89-90
} 
dan strategis secara cepat dan tepat, tetapi juga memilki kematangan kepribadian, siap menghadapi tantangan-tantangan baru dan berani keluar dari comfort zone. Mereka juga sosok pribadi yang mampu berfikir kritis dan kreatif sehingga senantiasa mampu secara cepat membaca peluang dan mampu hidup dengan alam yang bergejolak dinamis. ${ }^{19}$

\section{PENUTUP}

Berdasarkan uraian pembahasan di atas dapat ditarik beberapa kesimpulan sebagai berikut: pertama, meskipun berbagai upaya pemerintah maupun instansi lain baik dalam bentuk pelatihan, workshop, bimtek maupun bentuk lain yang bertujuan untuk peningkatkan kualitas mengajar guru masih belum sepenuhnya berhasil, namun hal ini tidak menjadi penghalang untuk tidak ikut berkontribusi dan berkompetisi dalam kancah persaingan pendidikan di era MEA. Kendati demikian upaya perbaikan dari diri guru itu sendiri suatu hal terpenting. Sebaik apapun materi pelatihan tentang peningkatan kualitas mengajar guru, tapi guru sendiri tidak ada keinginan untuk berubah semua akan sia-sia. Hal ini senada dengan pernyataan Renald Kasali sebagaimana pembahasan di atas bahwa perubahan bukanlah semata-mata mengubah alat, teknologi, sistem, organisasi dan sebagainya. Melainkan mengubah attitude melalui cara berfikir.

Kedua, perlu melakukan perubahan yang fundamental dalam diri guru. Hal yang fundamental yang menentukan perilaku tersebut yaitu mindset. Sedangkan mindset terdiri dari belief atau belief system yang mempengaruhi perilaku (behavior) dan sikap (attitude). Melakukan perubahan belief negatif menjadi belief positif. Implementasinya mengubah paradigma mengajar seorang guru dari mengajar hanya menyampaikan menjadi menanamkan keterampilan. Mengajar memenuhi jam saja menjadi mengajar untuk memenuhi kebutuhan peserta didik, dan mengajar untuk menggugurkan kewajiban menjadi mengajar membimbing dan menanamkan kepada peserta didik akan aspek kognitif, afektif dan psikomotorik.

Ketiga, untuk memenangkan persaingan pendidikan di era MEA, para guru harus memiliki mindset "driver", yaitu sosok pendidik yang mampu menjadi educator, inisiator, creator, motivator, generator, inspirator, dan role model bagi peserta

${ }^{19}$ Ibid. 
didik dan orang-orang di sekitarnya. Sebagai good driver, guru harus memiliki keseimbangan antara logic dengan hatinya. Mereka tidak cukup hanya bermodalkan tekad dan semangat, namun juga berbekal referensi dari pengetahuan akademis. Di samping itu, kinerjanya selalu didasarkan pada prinsip inisiatif, melayani, navigasi, dan tanggung jawab.

\section{DAFTAR PUSTAKA}

Amiruddin, Perencanaan Pembelajaran, Bantul Yogyakarta: Parama Ilmu, 2016.

Ali, Muhammad, Pendidikan untuk Pembangunan Nasional, Bandung: Imperial Bhakti Utama, 2009.

Chotib, Munif , Gurunya Manusia: Menjadikan Semua Anak Istimewa dan Semua Anak Juara, Bandung: Kaifa, 2014.

Gunawan, Adi W, The Secret of Mindset, Cet. III, Jakarta: Gramedia Pustaka Utama, 2008.

Kasali, Renald Kasali, dalam kata pengantar buku The Scecret of Mindset karya Andi W. Gunawan Jakarta: Gramedia Pustaka Utama, 2008.

Kasali, Renald, Self Driving: Menjadi Driver atau Passenger, Jakarta Selatan: Mizan, 2014.

Mulyasa, E, Pengembangan Implementasi Kurikulum 2013, Bandung: Remaja Rosdakarya, 2013.

Sanjaya, Wina, Strategi Pembelajaran Berorientasi Strandar Proses Penilaian, Jakarta: Prenada media, 2013.

Wong, Willy, Membongkar Rahasia Hipnotis, Cet. III, Jakarta: Visimedia, 2010.

Zahroni, Dinamika Peningkatan Mutu, Yogyakarta: Galvin Kalam Utama, 2011. 